\title{
Effect of Different Tree Spacings of Grewia optiva and Combined Doses of Poultry Manure and Vermicompost on Growth and Yield of Bell Pepper under Agrisilviculture System
}

\author{
S. Kar ${ }^{*}$, A. Chandel and K.S. Pant
}

Department of Silviculture and Agroforestry, Dr. YS Parmar University of Horticulture and Forestry, Nauni, Solan, Himachal Pradesh-173230, India

*Corresponding author

\section{A B S T R A C T}

\section{Keywords}

Agrisilviculture system, Grewia optiva, Bell pepper, Poultry manure, Vermicompost

Article Info

Accepted:

14 December 2018

Available Online:

10 January 2019

\begin{abstract}
A field trial was established to study the effect of four spacing $(8 \mathrm{~m} \times 1 \mathrm{~m}, 8 \mathrm{~m} \times 2 \mathrm{~m}, 8 \mathrm{~m} \times 3 \mathrm{~m}$ and open i.e. tree less area) of Grewia optiva trees, and eight manure doses treatment $\left(\mathrm{T}_{1}\right.$ to $\mathrm{T}_{6}-160 \%, 140 \%, 120 \%, 100 \%, 80 \%, 60 \%$ of recommended doses of nitrogen through vermicompost and poultry manure in 50-50 ratio respectively, $\mathrm{T}_{7}-100 \%$ of recommended doses of NPK (chemical fertiliser) and $\mathrm{T}_{8^{-}}$Control i.e. no manures and fertilisers) on growth and yield of bell pepper under agrisilviculture system. The benefit cost ratio increased upto $\mathrm{T}_{3}$, and then after decreased depicting that $120 \%$ of the recommended doses of nitrogen through vermicompost and poultry manure was the best treatment for the optimum yield of bell pepper, both under different spacings of agrisilviculture system and open condition. Agrisilviculture system integrating bell pepper with widely spaced Grewia optiva i.e. $8 \mathrm{~m} \times 3 \mathrm{~m}$ was found to be economically superior to sole cropping of bell pepper in open condition.
\end{abstract}

\section{Introduction}

Agroforestry is a collective name for land use systems and technologies where woody perennials (tree, shrubs, palms, bamboos, etc.) are deliberately used on the same land management units as agriculture crops and/or animals, in some form of spatial arrangement or temporal sequence. In agroforestry system there are both ecological and economical interactions between the different components (Lundgren and Raintree, 1982). It is a land use system which is capable of yielding both wood and food, while conserving and rehabilitating the ecosystems. It has the capability to increase the productivity and at the same time maintain the nutrient balance as well as protect the nature.

According to the State of Indian Agriculture report, India shares only 2.4 per cent of the world's land and only 4.0 per cent of the world's freshwater resources, but the agricultural sector has to cater 17.5 per cent of the world's population. The net sown area has been stagnant at about 140 million hectares 
and, in view of the competing demands for land, it is not likely to increase. Thus, for resolving the twin issues of food security and environmental quality that the country faces, natural resource management needs to be accorded the highest priority (Anonymous 2016). The increasing population is also imposing higher demands on the forest products and the fact is that, even today the production in forestry sector is not enough to meet out the existing demands, which is also bringing down the reserve forest under increased pressure. As per IPCC, agroforestry systems can provide significant opportunities of creating synergies linking both adaptation and mitigation actions with a technical mitigation potential of $1.1-2.2 \mathrm{Pg} \mathrm{C}$ in terrestrial ecosystems in coming 50 years (IPCC, 2007). Under such circumstances, agroforestry can be advantageous over traditional agricultural and forest production methods, in which the same unit of land can be exploited for production of diverse products in a sustainable basis, and at the same time secures livelihood of the farmers, checks soil degradation and maintains ecological balance.

According to Brandis (1972) Grewia optiva belonging to family Tiliaceae is distributed throughout the sub-Himalayan tract up to an altitude of $1800 \mathrm{~m}$ and is one of the most important multipurpose trees of north-western Himalayas. It provides nutritive and palatable fodder during the lean winter season, bast fibre and fuelwood. In addition, it also adds large quantities of organic matter to the soil through litter fall. Organic vegetable cultivation offers one of the most sustainable farming systems with recurring benefits not only to long term soil health but also provides a lasting stability in production by making it resistance to all kind of stress. Growing of bell pepper using organic manures under widely spaced Grewia optiva can offer economically more benefits than sole cropping of bell pepper in open condition when the tree component is properly managed. The information on these aspects of Grewia based agrisilviculture system involving vegetable crops and the use of organic manures is meager. There are still many unanswered questions, which require great deal of research.

\section{Materials and Methods}

\section{Site description}

The experiment was conducted in the existing agroforestry model of Grewia optiva in the department of Silviculture and Agroforestry, Dr. Y S Parmar University of Horticulture and Forestry, Nauni, Solan (H.P.) during the period of March, 2018 to August, 2018. The area is located at $30^{\circ} 51^{\prime} \mathrm{N}$ latitude and $76^{\circ}$ $11^{\prime}$ E longitude, with an elevation of $1200 \mathrm{~m}$ above MSL and slope of 7-8 percent, which falls in sub-tropical, sub-humid agro-climatic zone of Himachal Pradesh, India. The area receives an annual rainfall which varies from $1000-1400 \mathrm{~mm}$ and about 75 percent of it is received during the monsoon period (JuneSeptember). The average annual temperature is $17.4^{\circ} \mathrm{C}$. The soil of the area belongs to Typic Eutrochrept subgroup as per the soil taxonomy of USDA. The soil is gravelly sandy loam in texture and the $\mathrm{pH}$ of the top layer of the soil $(15 \mathrm{~cm})$ is neutral and containing high organic matter.

\section{Details of structural components}

Woody component of the agroforestry system i.e. Grewia optiva tree rows runs in East-West orientation. It was established in three different spacings $(8 \mathrm{~m} \times 1 \mathrm{~m}, 8 \mathrm{~m} \times 2 \mathrm{~m}$ and $8 \mathrm{~m} \times 3 \mathrm{~m})$, since July, 2004. The details of the growth attributes of the trees, and some physiological parameters like Leaf Area Index, Photosynthetically Active Radiations and Light Intensity under different spacings 
of the Grewia optiva tree rows are presented in the Table 1.

Bell pepper (Capsicum annuum L.), variety Solan Bharpur was grown with spacing of $60 \mathrm{~cm} \times 45 \mathrm{~cm}$, solely and also with Grewia trees, in plots of size $3 \mathrm{~m} \times 1 \mathrm{~m}$ accommodating 12 plants per plot. Nursery raised 60-65 days old seedlings were transplanted on $25^{\text {th }}$ of March, 2018. In addition, the effect of percentage increasing doses (60-160\%) of vermicompost and poultry manure on performance of bell pepper was also analysed.

\section{Design of the experiment and treatment details}

The experiment was established as per splitplot design, in which the main plot treatment (4) was tree spacing and sub plot treatment (8) was the manure doses, details of which are given in the Table 2. The total number of treatment combination was 32 and it was replicated thrice. In the treatment plots of $T_{1}$ $\mathrm{T}_{6}$, respective quantities of vermicompost and poultry manure were applied during soil preparation. For $\mathrm{T}_{7}$, full dose of SSP, MOP and half dose of urea was applied as basal application, and rest $1 / 2$ dose of urea was applied in 2 equal splits i.e. after 1 month of transplanting and during flowering.

\section{Parameters recorded}

Certain yield attributing parameters of the bell pepper like- days to first flowering, plant height, total number of fruits per plant, 1000 seed weight and fruit yield per hectare were assessed both under system and open condition. Data were collected from 5 randomly selected bell pepper plants (physiological maturity stage) in each plot. Under agroforestry system, parameters like Leaf Area Index (LAI) and Photosynthetically Active Radiation (PAR) were measured using the instrument CI-110 Digital Plant Canopy
Analyser, whereas, the light intensity was measured using Lux Meter. Economic parameters like net return and benefit cost ratio were analysed for estimating the economic viability of the treatment combinations. While estimating the cost of cultivation, due considerations were made to incorporate the initial establishment cost, and the annual lopping and fibre extraction cost by using the annuity method. And during return calculations, returns from leaf fodder, fibre and fuel wood was also considered. The data obtained from various characters under study were analyzed by the method of analysis of variance as described by (Gomez and Gomez, 1984).

\section{Results and Discussion}

Parameters of bell pepper such as days to first flowering, plant height, total number of fruits per plant, 1000 seed weight and fruit yield per hectare were recorded under three spacings of Grewia based agroforestry system as well as in open condition (Fig. 1).

\section{Days to first flowering}

Data presented in Table 3 reveals that, tree spacing and the manure doses had a significant influence on the number of days to first flowering of bell pepper under Grewia optiva. Days to first flowering decreased with increase in light intensity and PAR, longest span (35.85 days) being recorded under $S_{1}$ $(8 \mathrm{~m} \times 1 \mathrm{~m})$ spacing and shortest (31.80 days) under open condition $\left(\mathrm{S}_{0}\right)$. The prolonged duration of flowering under agroforestry system may be due to late initiation of bud formation under relatively more prolonged shade conditions. These results are in line with the findings of Hadi et al., (2006), Nasrullahzadeh et al., (2007). Further, under different manure doses, the longest span to first flowering (38.15 days) was recorded in $\mathrm{T}_{8}$ (no manures), while the shortest (30.84 
days) was recorded in $\mathrm{T}_{1}(160 \% \mathrm{OM})$, which was statistically at par with $\mathrm{T}_{2}(140 \% \mathrm{OM})$ i.e. 31.63 days to first flowering. The earliness in flowering in the plots treated with higher doses of organic manure (vermicompost and poultry manure), could be attributed due to the faster enhancement of vegetative growth and storing sufficient reserved food materials for differentiation of buds into flowers (Wolff and Coltman, 1990).

\section{Plant height (cm)}

Table 4 reveals that, under different spacings, bell pepper plant height was recorded maximum under open condition $\left(\mathrm{S}_{0}\right)$, i.e. $55.58 \mathrm{~cm}$ and then decreased with decrease in light intensity and PAR under agroforestry system from $S_{3}-S_{1}$. This may be attributed due to the decrease in competition for light, moisture and nutrients between the roots of trees and vegetable crop, with increase in distance from trees (Manurung et al., 2007). On the other hand, among the different manure doses, maximum plant height (55.59 $\mathrm{cm})$ was registered in $\mathrm{T}_{1}(160 \% \mathrm{OM})$, which was statistically at par with $\mathrm{T}_{2}(140 \% \mathrm{OM})$ and $\mathrm{T}_{7}(100 \% \mathrm{NPK})$, however minimum plant height $(47.47 \mathrm{~cm})$ was recorded in $\mathrm{T}_{8}$ (no manures) treatment. The differential response of plants to differed doses of organic manures is due to production of lesser quantity of growth-promoting substances by lower doses of organic manures than in higher doses (Arancon et al., 2004 b). In addition to these, vermicompost also contains micro nutrients such as Calcium, Magnesium, Zinc and Manganese, resulting in better plant height of capsicum.

\section{Total number of fruits per plant and fruit yield $\left(\mathbf{q ~ h a} \mathbf{~}^{-1}\right)$}

Perusal of the data presented in table 5 and 6 reveals that, tree spacing, organic manures and their interaction significantly influenced the total number of fruits per plant and the fruit yield per hectare. Among the four spacings, highest number of fruits per plant (14.18) and maximum fruit yield per hectare (216.12 q) were recorded in $\mathrm{S}_{0}$ (open) spacing, which were statistically at par with that of $\mathrm{S}_{3}(8 \mathrm{~m} \times 3 \mathrm{~m})$ spacing; however, lowest number of fruits per plant (9.72) and minimum fruit yield per hectare $(137.57 \mathrm{q})$ were recorded in $S_{1}(8 \mathrm{~m} \times 1 \mathrm{~m})$ spacing. There was an increasing trend of fruits per plant and fruit yield per hectare, with increase in spacing and increase in light intensity, this could be due to poor photosynthetic capacity and resource pool competition under the tree. These findings are in line with Manurung et al., (2007) and Islam et al., (2008) who reported higher yield per plant of Capsicum annuum and Chilli in plot without shade as compared with plots under full shade. Among the manure doses, the highest number of fruits per plant (14.87) and maximum fruit yield per hectare $(227.19 \mathrm{q})$ were recorded in $\mathrm{T}_{1}(160 \%$ $\mathrm{OM})$, which were statistically at par with $\mathrm{T}_{2}$ (140 \% OM). However, lowest number of fruits per plant (5.64) and minimum fruit yield per hectare (73.94 q) were registered in $\mathrm{T}_{8}$ (no manures). Number of fruits per plant and fruit yield per hectare in $\mathrm{T}_{7}(100 \% \mathrm{NPK})$ were found to be significantly at par with that $\left.\begin{array}{lllll}\text { of } & \mathrm{T}_{4} & (100 & \% & \mathrm{OM}\end{array}\right)$. The incremental advantages in terms of yield observed with the increasing dosage of organic manure may be due to the optimum nutrient supply to the capsicum plant, enhancing the growth and development by increasing the rate of plant metabolic processes like photosynthesis, respiration and their better acclimatization that encouraged greater green leaf area, helping in higher carbohydrate synthesis and leading to increase formation of plant metabolites that helped to build the plant tissue and yield attributes (Lego et al.) Besides, vermicompost also contains significant quantities of nutrients, a large amount of beneficial microbial populations 
and biologically active metabolites particularly, gibberellins, cytokinins, auxins and group B vitamins (Bhavalkar, 1991) all of which have a beneficial effect on photosynthesis and translocation, resulting in higher yield attributing factors. Similar results were obtained by Jamir et al., (2017), Gopinath et al., (2011) and Adhikari et al., (2016).A combined effect of treatment and spacing $(\mathrm{S} \times \mathrm{T})$ revealed that, highest number of fruits per plant (17.19) and maximum fruit yield per hectare $(271.51 \mathrm{q})$ were recorded in treatment combination $\mathrm{S}_{0} \mathrm{~T}_{1}$, which were significantly at par with $\mathrm{S}_{0} \mathrm{~T}_{2}$ and $\mathrm{S}_{0} \mathrm{~T}_{3}$. On the other hand, lowest number of fruits per plant (4.93) and minimum fruit yield per hectare (63.36 q) were recorded in $\mathrm{S}_{1} \mathrm{~T}_{8}$, which were found to be statistically at par with $\mathrm{S}_{2} \mathrm{~T}_{8}$ and $\mathrm{S}_{3} \mathrm{~T}_{8}$.

\section{0 seed weight $(g)$}

Data presented in Table 7 reflects that only manure doses had significant influence on the 1000 seed weight of capsicum. Maximum weight of 1000 seeds $(4.78 \mathrm{~g}$ ) was recorded in $\mathrm{T}_{1}(160 \% \mathrm{OM})$ and minimum $(4.10 \mathrm{~g})$ was recorded in $\mathrm{T}_{8}$ (no manures), which was statistically at par with $\mathrm{T}_{6}\left(\begin{array}{lll}60 & \% & \mathrm{OM}\end{array}\right)$ treatment. 1000 seed weight in $\mathrm{T}_{7}(100 \%$ NPK) i.e. $4.57 \mathrm{~g}$, was found to be statistically at par with $\mathrm{T}_{3}(120 \% \mathrm{OM})$ i.e. $4.54 \mathrm{~g}$. Heavier seeds might have resulted from greater accumulation of food reserves with application of higher quantity vermicompost and poultry manure. In addition Vermicompost contains several micro nutrients, among which boron helps in better seed quality. The results are in conformity with that of Sharma (1999) and Kumar and Sharma (2006).

\section{Economic analysis}

Economic analysis revealed that growing of bell pepper under wider spacing $(8 \mathrm{~m} \times 3 \mathrm{~m})$ of Grewia optiva proved to be more profitable than sole cropping of bell pepper in open condition. The cost of cultivation was more under agroforestry system as compared to the sole cropping of bell pepper; this is due to the additional cost incurred in the agroforestry system on the tree component for initial establishment, yearly lopping and fibre extraction. With the increase in manure doses rate, the cost of cultivation also increased. The cost of cultivation of bell pepper with inorganic fertilisers were less as compared all the organic manure treatments, this is due to the cheaper market prices of the inorganic fertilisers (Table 8). The net return (Rs. 4.08 lakh ha ${ }^{-1}$ ) and B:C (3.20) of bell pepper under $\mathrm{S}_{3}(8 \mathrm{~m} \times 3 \mathrm{~m})$ spacing was higher than the net return (Rs. 3.63 lakh ha $^{-1}$ ) and B:C (3.17) of sole cropping of bell pepper under open condition (Table 9 and 10). Net return increased with increase in organic manure rates upto treatment $\mathrm{T}_{1}$ (application of $160 \%$ of recommended dose of nitrogen through $\mathrm{VC}$ and $\mathrm{PM}$ ) in all spacings, however the marginal increment in the return reduced drastically after $\mathrm{T}_{3}$ (application of $120 \%$ of recommended dose of nitrogen through $\mathrm{VC}$ and PM).

Table.1 Details of the growth attributes of the trees

\begin{tabular}{|c|c|c|c|c|c|c|}
\hline Tree Spacing & $\begin{array}{c}\text { Tree } \\
\text { height } \\
(\mathbf{m})\end{array}$ & $\begin{array}{c}\text { D.B.H } \\
(\mathbf{c m})\end{array}$ & $\begin{array}{c}\text { Crown } \\
\text { spread } \\
(\mathbf{m})\end{array}$ & LAI & $\begin{array}{c}\text { PAR }(\boldsymbol{\mu m o l} \\
\left.\mathbf{m}^{\mathbf{2}} \mathbf{s}^{-1}\right)^{*}\end{array}$ & $\begin{array}{c}\text { Light } \\
\text { Intensity } \\
(\mathbf{L u x}) * *\end{array}$ \\
\hline $\mathbf{S}_{\mathbf{1}}(\mathbf{8 m} \times \mathbf{1 m})$ & 5.45 & 10.15 & 1.50 & 1.26 & 266.13 & 11044 \\
\hline $\mathbf{S}_{\mathbf{2}}(\mathbf{8 m} \times \mathbf{2 m})$ & 5.39 & 11.58 & 1.96 & 1.13 & 321.70 & 14498 \\
\hline $\mathbf{S}_{\mathbf{3}}(\mathbf{8 m} \times \mathbf{3 m})$ & 5.17 & 12.52 & 2.31 & 0.92 & 407.67 & 17725 \\
\hline
\end{tabular}

* PAR in open condition $\left(460.19 \mu \mathrm{mol} \mathrm{m} \mathrm{s}^{-1}\right)$; ** Light Intensity in open condition (19845 Lux) 
Table.2 Details of main plot and sub plot treatments

\begin{tabular}{|c|c|}
\hline Main plot treatment & Spacing (S) \\
\hline $\mathrm{S}_{1}$ & $8 \mathrm{~m} \times 1 \mathrm{~m}$ \\
\hline $\mathrm{S}_{2}$ & $8 \mathrm{~m} \times 2 \mathrm{~m}$ \\
\hline $\mathrm{S}_{3}$ & $8 \mathrm{~m} \times 3 \mathrm{~m}$ \\
\hline $\mathrm{S}_{0}$ & open condition \\
\hline Sub plot treatment & Manure doses (T) \\
\hline $\mathrm{T}_{1}$ & $160 \%$ RD N through VC \& PM on 50:50 N-equivalence basis \\
\hline $\mathrm{T}_{2}$ & $140 \%$ RD N through VC \& PM on 50:50 N-equivalence basis \\
\hline $\mathrm{T}_{3}$ & $120 \%$ RD N through VC \& PM on 50:50 N-equivalence basis \\
\hline $\mathrm{T}_{4}$ & $100 \%$ RD N through VC \& PM on 50:50 N-equivalence basis \\
\hline $\mathrm{T}_{5}$ & $80 \%$ RD N through VC \& PM on 50:50 N-equivalence basis \\
\hline $\mathrm{T}_{6}$ & $60 \%$ RD N through VC \& PM on 50:50 N-equivalence basis \\
\hline $\mathrm{T}_{7}$ & $100 \%$ RD NPK (chemical fertilizers- urea, SSP, MOP) \\
\hline $\mathrm{T}_{8}$ & Control (no fertilizer \& no manure) \\
\hline
\end{tabular}

Table.3 Effect of tree spacing and organic manures on days to first flowering of bell pepper after transplanting under Grewia based agrisilviculture system

\begin{tabular}{|c|c|c|c|c|c|}
\hline \multirow{2}{*}{$\begin{array}{l}\text { MANURE } \\
\text { DOSES }\end{array}$} & \multicolumn{4}{|c|}{ TREE SPACING } & \multirow[t]{2}{*}{ MEAN } \\
\hline & $\begin{array}{c}\mathrm{S}_{1} \\
(8 \mathrm{~m} \times 1 \mathrm{~m})\end{array}$ & $\begin{array}{c}\mathrm{S}_{2} \\
(8 \mathrm{~m} \times 2 \mathrm{~m})\end{array}$ & $\begin{array}{c}\mathrm{S}_{3} \\
(\mathbf{8} \mathrm{m} \times 3 \mathrm{~m})\end{array}$ & $\begin{array}{c}\mathbf{S}_{\mathbf{0}} \\
\text { (Open) }\end{array}$ & \\
\hline $\mathrm{T}_{1}(160 \% \mathrm{VC}+\mathrm{PM})$ & 32.32 & 31.52 & 30.89 & 28.62 & 30.84 \\
\hline $\mathrm{T}_{2}(140 \% \mathrm{VC}+\mathrm{PM})$ & 33.74 & 32.61 & 31.08 & 29.08 & 31.63 \\
\hline $\mathrm{T}_{3}(120 \% \mathrm{VC}+\mathrm{PM})$ & 35.08 & 33.43 & 32.03 & 29.88 & 32.61 \\
\hline $\mathrm{T}_{4}(100 \% \mathrm{VC}+\mathrm{PM})$ & 35.89 & 34.40 & 33.54 & 31.34 & 33.79 \\
\hline $\mathrm{T}_{5}(80 \% \mathrm{VC}+\mathrm{PM})$ & 36.43 & 35.91 & 34.58 & 32.84 & 34.94 \\
\hline $\mathrm{T}_{6}(60 \% \mathrm{VC}+\mathrm{PM})$ & 37.66 & 36.79 & 35.84 & 34.24 & 36.13 \\
\hline $\mathrm{T}_{7}(100 \% \mathrm{NPK})$ & 35.99 & 34.92 & 33.72 & 31.74 & 34.09 \\
\hline$T_{8}$ (no manures) & 39.71 & 38.93 & 37.31 & 36.65 & 38.15 \\
\hline MEAN & 35.85 & 34.82 & 33.62 & 31.80 & \\
\hline & & & \multirow[t]{3}{*}{$\mathrm{CD}_{0.05}$} & $\mathbf{S}$ & 1.11 \\
\hline & & & & $\mathbf{T}$ & 0.84 \\
\hline & & & & $S \times T$ & NS \\
\hline
\end{tabular}


Table.4 Effect of tree spacing and organic manures on plant height at harvest $(\mathrm{cm})$ of Bell Pepper under Grewia based agrisilviculture system

\begin{tabular}{|c|c|c|c|c|c|}
\hline \multirow{2}{*}{$\begin{array}{c}\text { MANURE } \\
\text { DOSES }\end{array}$} & \multicolumn{4}{|c|}{ TREE SPACING } & \multirow[t]{2}{*}{ MEAN } \\
\hline & $\begin{array}{c}S_{1} \\
(8 \mathrm{~m} \times 1 \mathrm{~m})\end{array}$ & $\begin{array}{c}\mathrm{S}_{2} \\
(\mathbf{8 m} \times 2 \mathrm{~m})\end{array}$ & $\begin{array}{c}\mathbf{S}_{\mathbf{3}} \\
(\mathbf{8 m} \times \mathbf{3 m})\end{array}$ & $\begin{array}{c}\mathbf{S}_{\mathbf{0}} \\
\text { (Open) }\end{array}$ & \\
\hline $\mathrm{T}_{1}(160 \% \mathrm{VC}+\mathrm{PM})$ & 52.97 & 53.66 & 56.96 & 58.77 & 55.59 \\
\hline $\mathrm{T}_{2}(140 \% \mathrm{VC}+\mathrm{PM})$ & 51.82 & 53.20 & 56.73 & 58.20 & 54.99 \\
\hline $\mathrm{T}_{3}(120 \% \mathrm{VC}+\mathrm{PM})$ & 50.33 & 52.52 & 55.27 & 56.74 & 53.72 \\
\hline $\mathrm{T}_{4}(100 \% \mathrm{VC}+\mathrm{PM})$ & 50.12 & 52.64 & 54.42 & 55.76 & 53.23 \\
\hline $\mathrm{T}_{5}(80 \% \mathrm{VC}+\mathrm{PM})$ & 49.61 & 50.78 & 52.41 & 53.15 & 51.49 \\
\hline $\mathrm{T}_{6}(60 \% \mathrm{VC}+\mathrm{PM})$ & 48.16 & 49.40 & 51.28 & 52.50 & 50.33 \\
\hline $\mathrm{T}_{7}(\mathbf{1 0 0 \%} \mathrm{NPK})$ & 51.96 & 53.85 & 56.04 & 58.65 & 55.13 \\
\hline $\mathrm{T}_{8}$ (no manures) & 46.05 & 46.92 & 46.00 & 50.90 & 47.47 \\
\hline MEAN & 50.13 & 51.62 & 53.64 & 55.58 & \\
\hline & & & \multirow[t]{3}{*}{$\mathrm{CD}_{0.05}$} & $\mathbf{S}$ & 0.87 \\
\hline & & & & $\mathbf{T}$ & 1.07 \\
\hline & & & & $\mathbf{S} \times \mathbf{T}$ & NS \\
\hline
\end{tabular}

Table.5 Effect of tree spacing and organic manures on total number of fruits per plant of bell pepper under Grewia based agrisilviculture system

\begin{tabular}{|c|c|c|c|c|c|}
\hline \multirow{2}{*}{$\begin{array}{c}\text { MANURE } \\
\text { DOSES }\end{array}$} & \multicolumn{4}{|c|}{ TREE SPACING } & \multirow{2}{*}{ MEAN } \\
\hline & $\begin{array}{c}S_{1} \\
(8 \mathrm{~m} \times 1 \mathrm{~m})\end{array}$ & $\begin{array}{c}S_{2} \\
(8 \mathrm{~m} \times 2 \mathrm{~m})\end{array}$ & $\begin{array}{c}S_{3} \\
(8 m \times 3 m)\end{array}$ & $\begin{array}{c}\mathbf{S}_{\mathbf{0}} \\
\text { (Open) }\end{array}$ & \\
\hline $\mathrm{T}_{1}(160 \% \mathrm{VC}+\mathrm{PM})$ & 11.91 & 14.30 & 16.09 & 17.19 & 14.87 \\
\hline $\mathrm{T}_{2}(140 \% \mathrm{VC}+\mathrm{PM})$ & 11.73 & 14.07 & 15.91 & 17.03 & 14.69 \\
\hline $\mathrm{T}_{3}(120 \% \mathrm{VC}+\mathrm{PM})$ & 11.55 & 13.71 & 15.61 & 16.82 & 14.42 \\
\hline $\mathrm{T}_{4}(100 \% \mathrm{VC}+\mathrm{PM})$ & 10.32 & 12.54 & 14.45 & 15.64 & 13.24 \\
\hline $\mathrm{T}_{5}(80 \% \mathrm{VC}+\mathrm{PM})$ & 8.84 & 11.02 & 12.76 & 13.32 & 11.48 \\
\hline $\mathrm{T}_{6}(60 \% \mathrm{VC}+\mathrm{PM})$ & 8.20 & 9.25 & 11.32 & 11.59 & 10.09 \\
\hline $\mathrm{T}_{7}(\mathbf{1 0 0 \%} \mathrm{NPK})$ & 10.26 & 12.46 & 14.37 & 15.07 & 13.04 \\
\hline $\mathbf{T}_{8}$ (no manures) & 4.93 & 5.14 & 5.73 & 6.75 & 5.64 \\
\hline MEAN & 9.72 & 11.56 & 13.28 & 14.18 & \\
\hline & & & \multirow[t]{3}{*}{$\mathrm{CD}_{0.05}$} & $\mathbf{S}$ & 1.34 \\
\hline & & & & $\mathbf{T}$ & 0.42 \\
\hline & & & & S $\times T$ & 0.97 \\
\hline
\end{tabular}


Table.6 Effect of tree spacing and organic manures on fruit yield ( $\mathrm{q} \mathrm{ha}^{-1}$ ) of bell pepper under Grewia based agrisilviculture system

\begin{tabular}{|c|c|c|c|c|c|}
\hline \multirow{2}{*}{$\begin{array}{c}\text { MANURE } \\
\text { DOSES }\end{array}$} & \multicolumn{4}{|c|}{ TREE SPACING } & \multirow[t]{2}{*}{ MEAN } \\
\hline & $\begin{array}{c}\mathrm{S}_{1} \\
(\mathbf{8 m} \times \mathbf{1 m})\end{array}$ & $\begin{array}{c}S_{2} \\
(8 m \times 2 m)\end{array}$ & $\begin{array}{c}S_{3} \\
(8 m \times 3 m)\end{array}$ & $\begin{array}{c}\mathbf{S}_{\mathbf{0}} \\
\text { (Open) }\end{array}$ & \\
\hline $\mathrm{T}_{1}(160 \% \mathrm{VC}+\mathrm{PM})$ & 173.01 & 213.49 & 250.77 & 271.51 & 227.19 \\
\hline $\mathrm{T}_{2}(140 \% \mathrm{VC}+\mathrm{PM})$ & 170.06 & 209.19 & 246.51 & 267.78 & 223.38 \\
\hline $\mathrm{T}_{3}(120 \% \mathrm{VC}+\mathrm{PM})$ & 165.46 & 204.98 & 241.89 & 263.27 & 218.90 \\
\hline $\mathrm{T}_{4}(100 \% \mathrm{VC}+\mathrm{PM})$ & 146.58 & 185.91 & 220.71 & 236.92 & 197.53 \\
\hline $\mathrm{T}_{5}(80 \% \mathrm{VC}+\mathrm{PM})$ & 122.84 & 160.33 & 189.24 & 197.62 & 167.51 \\
\hline $\mathrm{T}_{6}(60 \% \mathrm{VC}+\mathrm{PM})$ & 113.91 & 131.73 & 165.92 & 168.87 & 145.11 \\
\hline $\mathrm{T}_{7}(100 \% \mathrm{NPK})$ & 145.32 & 185.87 & 217.83 & 233.13 & 195.54 \\
\hline $\mathbf{T}_{8}$ (no manures) & 63.36 & 66.85 & 75.70 & 89.83 & 73.94 \\
\hline MEAN & 137.57 & 169.79 & 201.07 & 216.12 & \\
\hline & & & \multirow[t]{3}{*}{$\mathrm{CD}_{0.05}$} & $\mathbf{S}$ & 18.42 \\
\hline & & & & $\mathbf{T}$ & 6.22 \\
\hline & & & & $\mathbf{S} \times \mathbf{T}$ & 14.31 \\
\hline
\end{tabular}

Table.7 Effect of tree spacing and organic manures on 1000 seed weight (g) of Bell Pepper under Grewia based agrisilviculture system

\begin{tabular}{|c|c|c|c|c|c|}
\hline \multirow{2}{*}{$\begin{array}{c}\text { MANURE } \\
\text { DOSES }\end{array}$} & \multicolumn{4}{|c|}{ TREE SPACING } & \multirow[t]{2}{*}{ MEAN } \\
\hline & $\begin{array}{c}S_{1} \\
(\mathbf{8 m} \times \mathbf{1 m})\end{array}$ & $\begin{array}{c}S_{2} \\
(8 m \times 2 m)\end{array}$ & $\begin{array}{c}\mathrm{S}_{\mathbf{3}} \\
(\mathbf{8 m} \times \mathbf{3 m})\end{array}$ & $\begin{array}{c}\mathbf{S}_{\mathbf{0}} \\
\text { (Open) }\end{array}$ & \\
\hline $\mathrm{T}_{1}(160 \% \mathrm{VC}+\mathrm{PM})$ & 4.75 & 4.77 & 4.79 & 4.81 & 4.78 \\
\hline $\mathrm{T}_{2}(140 \% \mathrm{VC}+\mathrm{PM})$ & 4.75 & 4.73 & 4.76 & 4.72 & 4.74 \\
\hline $\mathrm{T}_{3}(120 \% \mathrm{VC}+\mathrm{PM})$ & 4.56 & 4.58 & 4.52 & 4.51 & 4.54 \\
\hline $\mathrm{T}_{4}(100 \% \mathrm{VC}+\mathrm{PM})$ & 4.38 & 4.45 & 4.41 & 4.37 & 4.40 \\
\hline $\mathrm{T}_{5}(80 \% \mathrm{VC}+\mathrm{PM})$ & 4.28 & 4.30 & 4.31 & 4.34 & 4.31 \\
\hline $\mathrm{T}_{6}(60 \% \mathrm{VC}+\mathrm{PM})$ & 4.08 & 4.07 & 4.14 & 4.14 & 4.11 \\
\hline $\mathrm{T}_{7}(\mathbf{1 0 0 \%} \mathrm{NPK})$ & 4.55 & 4.55 & 4.58 & 4.60 & 4.57 \\
\hline $\mathbf{T}_{8}$ (no manures) & 4.04 & 4.09 & 4.11 & 4.15 & 4.10 \\
\hline MEAN & 4.43 & 4.44 & 4.45 & 4.46 & \\
\hline & & & \multirow[t]{3}{*}{$\mathrm{CD}_{0.05}$} & $\mathbf{S}$ & NS \\
\hline & & & & $\mathbf{T}$ & 0.03 \\
\hline & & & & $\mathbf{S} \times \mathbf{T}$ & NS \\
\hline
\end{tabular}


Table.8 Cost of cultivation (Rs. lakh ha ${ }^{-1}$ ) of bell pepper under Grewia based agrisilviculture system

\begin{tabular}{|c|c|c|c|c|c|}
\hline \multirow{2}{*}{$\begin{array}{l}\text { MANURE } \\
\text { DOSES }\end{array}$} & \multicolumn{4}{|c|}{ TREE SPACING } & \multirow[t]{2}{*}{ MEAN } \\
\hline & $\begin{array}{c}\mathrm{S}_{1} \\
(8 \mathrm{~m} \times 1 \mathrm{~m})\end{array}$ & $\begin{array}{c}\mathrm{S}_{2} \\
(8 \mathrm{~m} \times 2 \mathrm{~m})\end{array}$ & $\begin{array}{c}\mathrm{S}_{3} \\
(\mathbf{8 m} \times \mathbf{3 m})\end{array}$ & $\begin{array}{c}\mathbf{S}_{\mathbf{0}} \\
\text { (Open) }\end{array}$ & \\
\hline $\mathrm{T}_{1}(160 \% \mathrm{VC}+\mathrm{PM})$ & 2.27 & 2.24 & 2.22 & 2.04 & 2.19 \\
\hline $\mathrm{T}_{2}(140 \% \mathrm{VC}+\mathrm{PM})$ & 2.18 & 2.16 & 2.14 & 1.95 & 2.11 \\
\hline $\mathrm{T}_{3}(120 \% \mathrm{VC}+\mathrm{PM})$ & 2.10 & 2.07 & 2.06 & 1.87 & 2.03 \\
\hline $\mathrm{T}_{4}(100 \% \mathrm{VC}+\mathrm{PM})$ & 2.02 & 1.99 & 1.98 & 1.79 & 1.95 \\
\hline $\mathrm{T}_{5}(80 \% \mathrm{VC}+\mathrm{PM})$ & 1.94 & 1.91 & 1.90 & 1.71 & 1.86 \\
\hline $\mathrm{T}_{6}(60 \% \mathrm{VC}+\mathrm{PM})$ & 1.86 & 1.83 & 1.81 & 1.63 & 1.78 \\
\hline$T_{7}(100 \%$ NPK $)$ & 1.67 & 1.64 & 1.63 & 1.44 & 1.60 \\
\hline$T_{8}$ (no manures) & 1.06 & 1.03 & 1.02 & 0.83 & 0.99 \\
\hline MEAN & 1.89 & 1.86 & 1.84 & 1.66 & \\
\hline
\end{tabular}

Table.9 Net return (Rs. lakh ha ${ }^{-1}$ ) from bell pepper under Grewia based agrisilviculture system

\begin{tabular}{|c|c|c|c|c|c|}
\hline \multirow{2}{*}{$\begin{array}{c}\text { MANURE } \\
\text { DOSES }\end{array}$} & \multicolumn{4}{|c|}{ TREE SPACING } & \multirow[t]{2}{*}{ MEAN } \\
\hline & $\begin{array}{c}S_{1} \\
(8 \mathrm{~m} \times 1 \mathrm{~m})\end{array}$ & $\begin{array}{c}S_{2} \\
(8 \mathrm{~m} \times 2 \mathrm{~m})\end{array}$ & $\begin{array}{c}\mathrm{S}_{3} \\
(8 \mathrm{~m} \times 3 \mathrm{~m})\end{array}$ & $\begin{array}{c}\mathbf{S}_{\mathbf{0}} \\
\text { (Open) }\end{array}$ & \\
\hline $\mathrm{T}_{1}(160 \% \mathrm{VC}+\mathrm{PM})$ & 3.78 & 4.32 & 5.04 & 4.75 & 4.47 \\
\hline $\mathrm{T}_{2}(140 \% \mathrm{VC}+\mathrm{PM})$ & 3.79 & 4.29 & 5.02 & 4.74 & 4.46 \\
\hline $\mathrm{T}_{3}(120 \% \mathrm{VC}+\mathrm{PM})$ & 3.76 & 4.27 & 4.99 & 4.71 & 4.43 \\
\hline $\mathrm{T}_{4}(100 \% \mathrm{VC}+\mathrm{PM})$ & 3.37 & 3.87 & 4.54 & 4.13 & 3.98 \\
\hline $\mathrm{T}_{5}(80 \% \mathrm{VC}+\mathrm{PM})$ & 2.86 & 3.31 & 3.83 & 3.23 & 3.31 \\
\hline $\mathrm{T}_{6}(60 \% \mathrm{VC}+\mathrm{PM})$ & 2.72 & 2.68 & 3.33 & 2.59 & 2.83 \\
\hline $\mathbf{T}_{7}(\mathbf{1 0 0 \%} \mathbf{N P K})$ & 2.96 & 3.29 & 3.73 & 3.22 & 3.30 \\
\hline$T_{8}$ (no manures) & 2.25 & 1.86 & 1.87 & 1.41 & 1.85 \\
\hline MEAN & 3.19 & 3.49 & 4.04 & 3.60 & \\
\hline
\end{tabular}

Table.10 B C of growing Bell Pepper under Grewia based agrisilviculture system

\begin{tabular}{|c|c|c|c|c|c|}
\hline \multirow{2}{*}{$\begin{array}{c}\text { MANURE } \\
\text { DOSES }\end{array}$} & \multicolumn{4}{|c|}{ TREE SPACING } & \multirow[t]{2}{*}{ MEAN } \\
\hline & $\underset{(8 \mathrm{~m} \times 1 \mathrm{~m})}{\mathrm{S}_{1}}$ & $\begin{array}{c}\mathrm{S}_{2} \\
(8 \mathrm{~m} \times 2 \mathrm{~m})\end{array}$ & $\begin{array}{c}\mathrm{S}_{3} \\
(\mathbf{8 m} \times \mathbf{3 m})\end{array}$ & $\begin{array}{c}\mathbf{S}_{\mathbf{0}} \\
\text { (Open) }\end{array}$ & \\
\hline $\mathrm{T}_{1}(160 \% \mathrm{VC}+\mathrm{PM})$ & 2.67 & 2.93 & 3.27 & 3.33 & 3.05 \\
\hline $\mathrm{T}_{2}(140 \% \mathrm{VC}+\mathrm{PM})$ & 2.74 & 2.99 & 3.34 & 3.43 & 3.12 \\
\hline $\mathrm{T}_{3}(120 \% \mathrm{VC}+\mathrm{PM})$ & 2.79 & 3.06 & 3.42 & 3.52 & 3.20 \\
\hline $\mathrm{T}_{4}(\mathbf{1 0 0 \%} \mathrm{VC}+\mathrm{PM})$ & 2.67 & 2.94 & 3.30 & 3.31 & 3.05 \\
\hline $\mathrm{T}_{5}(80 \% \mathrm{VC}+\mathrm{PM})$ & 2.47 & 2.73 & 3.02 & 2.89 & 2.78 \\
\hline $\mathrm{T}_{6}(60 \% \mathrm{VC}+\mathrm{PM})$ & 2.46 & 2.47 & 2.84 & 2.59 & 2.59 \\
\hline $\mathrm{T}_{7}(\mathbf{1 0 0 \%} \mathrm{NPK})$ & 2.77 & 3.00 & 3.29 & 3.24 & 3.08 \\
\hline $\mathbf{T}_{8}$ (no manures) & 3.12 & 2.79 & 2.84 & 2.70 & 2.86 \\
\hline MEAN & 2.71 & 2.87 & 3.16 & 3.13 & \\
\hline
\end{tabular}

*NS- Non Significant at $\mathrm{P}>0.05$ 
Fig.1 Bell pepper under Grewia based agrisilviculture system

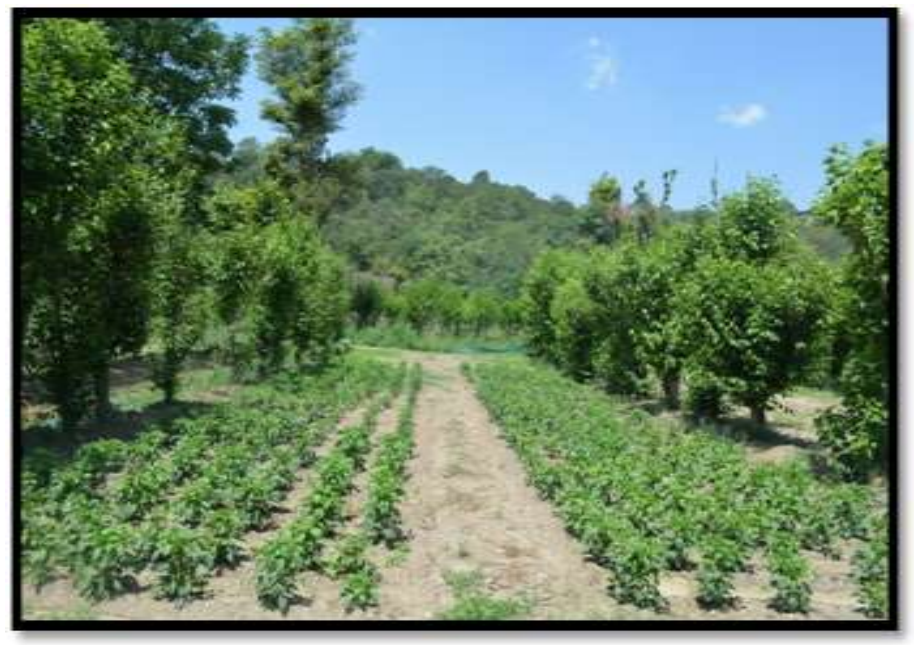

The Benefit Cost Ratio increased upto $\mathrm{T}_{3}(120$ $\% \mathrm{OM})$ and thereafter with the increase in organic manure rates, it decreased. So it is clearly evident that, $\mathrm{T}_{3} \quad(120 \%$ of recommended dose of nitrogen through $\mathrm{VC}$ and $\mathrm{PM}$ ) is the most economically profitable treatment dose and treatment combination of $\mathrm{S}_{3} \mathrm{~T}_{3}$ was the best treatment combination.

In conclusion the growth and yield parameters of bell pepper increased with the increase in tree spacing of Grewia optiva and rate of organic manure application. Among the different manure doses the treatment $\mathrm{T}_{3}$ (application of $120 \%$ of recommended dose of nitrogen through $\mathrm{VC}$ and PM) was proved to be the best dose, on the other hand, among different treatment combinations $\mathrm{S}_{3} \mathrm{~T}_{3}$ was the best as compared to others. The yield reduction in bell pepper under agroforestry system ranged between $6.96 \%-36.35 \%$ as compared to sole cropping of bell pepper. The income generated from the fodder, fibre and fuel wood of Grewia not only compensated the yield reduction of bell pepper under tree, but also increased the overall income of the farmers, apart from providing certain other indirect benefits like carbon sequestration, prevention of soil erosion, crop diversification and maintenance of micro-climate.

\section{References}

Adhikari P, Khanal A and Subedi R. 2016. Effect of different sources of organic manure and chemical fertilizers on growth and yield of sweet pepper. Advances in Plants and Agriculture Research 3(5):158-161.

Anonymous. 2016. State of Indian Agriculture, Government of India, Ministry of Agriculture \& Farmers Welfare, Department of Agriculture, Cooperation \& Farmers Welfare, Directorate of Economics \& Statistics, New Delhi.

Arancon NQ, Edwards CA, Bierman P, Welch C, and Metzger JD. 2004. Influence of vermicomposts on field strawberries: 1. effects on growth and yields. Bioresource Technology 93(2): 145-153.

Bhawalkar US. 1991. Vermiculture biotechnology for LEISA. In: Seminar on Low External Input Sustainable Agriculture held at Amsterdam, Netherlands. Pp. 1-6.

Brandis D. 1972. Indian Trees. Bishen Singh Mahendra Paul Singh, Dehradun, India. p767.

Gomez LA and Gomez AA. 1984. Statistical 
Procedure for Agricultural Research. John Wiley and Sons, Singapore. p 680.

Gopinath KA, Saha S, Mina BL, Kundu S and Gupta HS. 2011. Effect of organic manures and integrated nutrient management on yield potential of bell pepper (Capsicum annuи L.) varieties and on soil properties. Journal of Agronomy and Soil Science 54:127-137.

Hadi H, Ghassemi GK, Khoei RF, Valizadeh M and Shakiba MR. 2006. Response of common bean (Phaseolus vulgaris L.) to different levels of shade. Journal of Agronomy. 5:595-599.

Intergovernmental Panel on Climate Change (IPCC). 2007. Geneva, Switzerland. Assessment Report. p73.

Islam KK, Pervin MJ, Rashid MH, Mondol MA and Rahim MA. 2008. Performance of winter vegetables grown under coconut lemon based multistrata agroforestry system. Tropical and Subtropical Agroecosystems 8:165-170.

Jamir T, Rajwade VB, Prasad VM and Lyngdoh C. 2017. Effect of organic manures and chemical fertilizers on growth and yield of sweet pepper (Capsicum annuиm L.) hybrid Indam Bharath in shade net condition. International Journal of Current Microbiology and Applied Sciences 6:1010-1019.

Kumar S and Sharma SK. 2006. Effect of different methods of biofertilizer application in tomato seed production.
Seed Research 34:15-19.

Lego M, Singh D and Tsanglao S. 2016. Effect of different levels of NPK on growth, yield and economic of capsicum (Capsicum annuum L.) cv. Asha under shade net house cultivation. International Journal of Agricultural Science and Research 6:5-8.

Lundgren B and Raintree JB. 1982. Sustained Agroforestry. In: Agricultural research for development; potentials and challenges in Asia (B Nestel. ed.). INSAR, The Hague. pp 37- 49.

Manurung G, Susila AD, Roshetko J and Palada MC. 2007. Findings and Challenges: Can Vegetables be Productive under Tree Shade Management in West Java?. SANREM -TMPEGS Publication. $\mathrm{p}$ 17.

Nasurullahzadeh S, Ghassemi GK, Javanshir A, Valizadeh M and Shakiba MR. 2007. Effect of shade stress on ground cover and grain yield of faba bean (Vicia faba L.). Journal of Food, Agriculture and Environment 5:337340.

Sharma SK. 1999. Effect of boron and calcium on seed production of bell pepper (Capsicum annuит L.). Vegetable Science 26:87-88.

Wolff XY and Coltman RR. 1990. Productivity of eight leafy vegetable crops grown under shade in Hawaii. Journal of American Society for Horticultural Science 115:182-188.

\section{How to cite this article:}

Kar, S., A. Chandel and Pant, K.S. 2019. Effect of Different Tree Spacings of Grewia optiva and Combined Doses of Poultry Manure and Vermicompost on Growth and Yield of Bell Pepper under Agrisilviculture System. Int.J.Curr.Microbiol.App.Sci. 8(01): 2213-2223. doi: https://doi.org/10.20546/ijcmas.2019.801.231 